\title{
Constraint as an Ethical Postulate in the Context of Ecological Limits
}

\author{
Iwona Stachowska \\ (The Maria Grzegorzewska University in Warsaw, ivsta@wp.pl)
}

What to do to want less?

Hanna Krall

It is not so much a matter of giving more as of taking less.

Serge Latouche

In order to live better, we now have to produce and consume differently, to do better and more with less.

André Gorz

\section{Introduction}

"What to do to want less?" (Krall 2015). Hanna Krall asked Leszek Kołakowski that question almost half a century ago but still, it remains valid. It can be even said that nowadays it has become even more compelling and turned out to be a vital problem that requires to be solved. In times of a growing ecological crisis pertinent to the depletion of the planet's resources, increasing environmental and social costs, such as climate changes threats to biodiversity, deepening social inequalities and discrepancies between developed and developing countries, it is not easy not to see that the paradigm of the exponential economic growth seems unfeasible to maintain. The attachment to the growing GDP, to the welfare defined in material categories and to the everyday comfort is so strong that it is not easy to get out of that iron cage of the growth.

"How is it that with so much stuff already we still hunger for more?" asks Tim Jackson (2009, p. 4) anticipating, in the logical order, the aforementioned question - What to do to want less? Where and how to define the limits of growth? How to reconcile the financial capital with the natural and social ones? The response to these questions is to seek for alternative ways of thinking and development, different from those measured and driven by the GDP index. An essential element of the degrowth and sustainable strategies of development is a reference to the constraint category both in the qualitative and quantitative contexts. The paper will try to demonstrate that the constrain category, which is a counterweight to the unbridled growth is not only a politico-economic strategy but also an ethical postulate. 
Let us take a closer look at the contexts in which constraint occurs in the prosperity without growth project proposed by Tim Jackson and in Serge Latouche's proposition of de-growth (La Décroissance).

\section{Ecological Limits, i.e. a Planet with Limited Capabilities}

Key issue, in the case of a critique of the paradigm of constantly growing profits, production, consumption, increasing efficiency, and at the same time growing debt, is a strong and clear articulation of inevitability of a clash with the social, economic, and ecological limits. The basic idea here is to rebut the belief that economic growth and increase in wealth may unceasingly indicate the main direction of the progress of civilisation, and thus show how risky is sustaining the illusion of growth that stands in contradiction to the finite resources of the planet. Every kind of growth within the framework of a limited system must come to an end. Hence, it is legitimate to ask when it will happen, as well as an attempt to prevent it from happening, but not the considerations weather the resources get exhausted (see: Jackson 2009, pp. 118; Latouche 2009, pp. 23-25; Popkiewicz 2012, pp. 100-104).

It is a kind of argumentation that various authors refer to. Jackson is one of them. For him the problem of reconciling out will for a good life with the limited capabilities of the natural environment to satisfy that will is a starting point for looking for alternative ways of development (see: Jackson 2009, pp. 23). This British economist working for the Sustainable Development Commission, in his book Prosperity Without Growth: Economics for a Finite Planet, which is an enhanced version of the 2003 report published by that commission under the title Redefying Prosperity (SDC 2003), writes: "Any credible vision of prosperity has to address the question of limits. This is particularly true of a vision based on growth. How - and for how long - is continued growth possible without coming up against the ecological limits of a finite planet?" (Jackson 2009, pp. 5-6).

The problem of defining the growth limits is not, of course, a new one, but it is still very current and highly debated. Its roots are traced to the formulated at the turn of the $18^{\text {th }}$ century by Thomas Robert Malthus the "principle of population," which sense is conveyed in an observation that geometrical growth of population occurs quicker than the arithmetic growth of efficiency of soil and food production necessary to address the basic needs of that population, what inevitably leads to a crucial point where the number of people exceeds the level of availability of resources (Malthus 2003; Jackson 2009, pp. 6-7). Although the scenario predicted by the Anglican priest has not become a reality - in time the pace of population growth slowed down and technological development has made the necessary means of survival growing faster than the number of people - the recognition of the finite capabilities of the environment is extremely valuable. 
Garrett Hardin writes in a similar vein. In the published in 1968 article The Tragedy of the Commons he refers to the example of pasture and explains how seemingly trivial decisions on exploitation of common goods (pasture) result in destruction of shared resources (Hardin 1968, pp. 1243-1248). Unlimited access to limited common goods and their irresponsible use lead to their depletion, i.e. the title tragedy. Therefore, in result, all (current and potential) users of the resources lose, regardless the fact that it was in no-one's interest. "A finite world can support only a finite populations" - writes Hardin (Hardin 1968, p. 1243). What is interesting, the American biologist sees the solution to that problem not in new technologies that would be able to reduce negative effects of human impact on the natural environment, e.g. thanks to the introduction of new alternative methods of obtaining food or energy, but in the change of the moral nature. That is why he sees the rescue only in social contract limiting individuals in their access to common goods.

Perhaps the most known document associated with the problem of ecological limits and the limits of growth is a report prepared in the 1970s under the aegis of the Club of Rome entitled Limits to Growth (Meadows, Meadows, Rander, \& Behrens III 1972). Donatella and Dennis Meadows and the team, taking into account an exponential growth of economic activity, resource use, and the number of population, prepared a computer-based model that forecasted reaching a turning point, where significant shortages of resources will occur. According to their prognosis, we were to face the limits of growth at the beginning of the $21^{\text {st }}$ century. Catastrophic predictions included in the first report of the Club of Rome and stemming from it the zero growth postulate as a necessary direction of economic development change were immediately criticised. They brought about resistance especially among the pro-growth economists. For, accepting the conclusions stemming from the simulations and recognition of the vision of a global catastrophe was related to a profound alteration of the established economic paradigms and the whole socioeconomic model. In practice, the attachment to evaluation of market and nonmarket processes in categories of financial effectiveness turned out to be stronger. Eventually, the prognoses included in the report were in principle marginalized. The sceptics' beliefs were supported by the fact that apart from the rapid and unequivocal 2008 financial crisis no catastrophe has happened (Popkiewicz 2012, pp. 97-104). The resources were not depleted, the apparition of oil peak has been postponed in time, and the climate change progresses slowly and is not spectacular enough to catch the attention and divert the pro-growth trend. It is clear then that - what was rightly noticed by Zbigniew Hull, who referred to the metaphor of Aurelio Peccei - "the idea and practice of sustainable development loses against the god of growth that seized the world" (Hull 2008, p. 31). Meanwhile, as it is shown by numerous analyses and reports, including the Graham Turner's book A Comparison of the Limits to Growth with Thirty Years of Reality (2008), Charles Hall's and W. Day's article 
Revisiting the Limits to Growth After Peak Oil (2009, pp. 230-237), or the book Limits to Growth: The 30-Year Update (Meadows, Randers, \& Meadows 2004) written by the authors of the original report, the prognoses from 40 years ago are still valid, or at least have not changed enough to alter the conclusions from the previous publication. The postulate of limiting the growth is also still relevant and it continually stimulates the search for alternative concepts of development, such as the ones worked out by Jackson or Latouche.

Ecological limit of a different kind that should not be omitted is the problem of the capability of ecosystems and the biosphere to assimilate the effects of fast and energy-consuming economic activity, especially the overproduction and consumption of goods harmful to the environment. Ecological risk stemming from that (the rise of temperature, rising water levels, decline in biodiversity, contamination of soil and water, deforestation) is one of the most important challenges that we have ever had to face. "Even before we run out of oil, we're running out of planet" - quotes Jackson after Bill McKibb and emphasises the limited capability of the climate to absorb increasingly growing greenhouse emissions (Jackson 2009, p. 11). The 2006 Stern Report (2007) analyses the impact of global warming on global economy and points out the necessity to tackle the climate change. It also alerts to the consequences of failing to carry out actions aiming at creating low-emissions economy. Nicolas Stern using the language of economic analyses that treat the biosphere as a part of economy tried to show that it is worthy to invest in climate protection because it pays off economically. The British economist argued that it is possible to protect the climate without a radical limitation of economic growth, which was the main point of his standpoint (Stern 2007, pp. i-ix; see also: Stern 2010, pp. 16-19). Dieter Helm perceived Stern's diagnosis as too optimistic - "The easy compatibility between economic growth and climate change, which lies at the heart of the Stern Report, is an illusion" (Helm 2009; see also: Jackson 2009, p. 85). Maintaining the growth at the current level with the simultaneous high cost of investment in renewable energy sources and ecosystem protection is, according to the economist specialising in energy issues, impossible. Martin L. Weitzman, on the other hand, criticised a low discount rate $(1.4 \%)$, which was adopted by Stern for his calculations by showing that with a higher discount rate $(6 \%)$ investing in climate protection seizes to be profitable in the narrow economic sense (see: Weitzman 2007; Popkiewicz 2012, p. 340). The vision of sustaining the growing trends was undoubtedly a tempting scenario. Unfortunately, it also raised an invitation contrary to Stern's intentions - to stay with the current consumer habits and thereby to linger in the trap of growth.

Consumer society maintains the illusion of constant growth and is seduced not so much by the freedom of unlimited gathering of material goods but rather by a quick getting rid of them. It is facilitated, on the one hand, by the chase after novelty, and on the other, the planned and accelerated aging of 
products. However, as noted by Zygmunt Bauman - "The cult of novelty may be a manifestation of false awareness that obscures the truth that one is driven by not the desire of new things, but rather the urge to clean up the field; this awareness however is necessary for self-recreation of the economy based on quick circulation of products and the increase of the amount of money changing hands, i.e. GDP (Bauman 2015, p. 43; own transl.). Serge Latouche strongly opposes that mechanism. The French economist and philosopher, one of the main theoreticians and propagators of the degrowth idea (fr. décroissance), criticises the logic of consumerism based on the model: novelty excess, more - better, and sees in it the main threat for the stable future of the planet (Latouche 2009, pp. 16-20, 23-25). He inculpates the ideology glorifying consumerism for littering and polluting the environment, excessive exploitation of energy, consuming vast amounts of natural resources, destruction of forests, high emissions of greenhouse gases, and finally the increase of social and economic inequalities, including the production and ecological exploitation of poor countries, whose human and natural resources developed economies willingly use and export in exchange tonnes of toxic waste, mainly electronic and electric rubbish (Latouche 2009, pp. 19, 37). As reported by the European Environmental Agency over 15000 tonnes of colour TV sets were exported from the European Union to African countries in 2005 (EEA Signals 2009, p. 36). Taking into account the fact that these data are underestimated and the overall export of e-waste is much larger and that just $14 \%$ of it undergoes recycling and the rest is deposited on waste dumps, it is no surprise that ecological debt of the developed countries of the North to the developing countries of the South is so often mentioned (see: Latouche 2009, p. 37; Jackson 2009, pp. 84-85; WWF 2006, p. 25). By transferring the costs of the present consumption onto the natural environment, poor countries, and future generations we are dangerously getting closer to ecological limits that cannot be taken into account while planning future actions. Both Latouche and Jackson agree that under current circumstances fuelling consumption that drives the growth is a manifestation of extraordinary irresponsibility (see: Latouche 2009, pp. 16-30; Jackson 2009, pp. 87-102). What scenario then could become an alternative for the consumer exploitation of the globe?

\section{Degrowth, i.e., Quantitative and Qualitative Constraint}

The growth dilemma we face is a choice between a continuation of unsustainable growth, bought by an increasing depletion of resources, environmental costs and growing social inequalities, and an uncertain degrowth that under the present conditions may lead to a collapse of consumption, drop in production, increase of unemployment, recession and bankruptcy (see: Jackson 2009, p. 64-65; Latouche 2009, p. 3-4; Popkiewicz 2012, p. 96). In such a form the problem appears rather as an apparent 
dilemma. The short-term profit-and-loss account pleads in favour of the first solution, although its choice is a "dead end" restricted by ecological limits. If we, however, take a broader look and realise what Jackson turns the attention to "In pursuit of the good life today, we are systematically eroding the basis for well-being tomorrow. We stand in real danger of losing any prospect of a shared and lasting prosperity" (Jackson 2009, p. 2) - then it may transpire that degrowth is the only reasonable strategy for the future. "The alternative really is: de-growth or barbarism" - tellingly sums up Latouche $(2009$, p. 8) with reference to a title of one of the books of a political scientist, Paul Ariés (2005).

The term décroissance, degrowth in English, came into existence as a depiction referring in a narrower sense to the economic model aiming at a decrease of economic production, and in a broader context, as an idea pertinent to socio-political change. Latouche explains: "The de-growth society project is eminently revolutionary. We are taking about cultural change, as well as changes in the legal structure and relations of production" (Latouche 2009, p. 66). In other places he adds: "De-growth is a political project in the strong sense of the term. It means building convivial societies that are autonomous and economical in both the North and the South" (Latouche 2009, p. 32); "Its goal is to build a society in which we can live better lives whilst working less and consuming less" (Latouche 2009, p. 9). The French researcher emphasises that degrowth should not be confused with aforementioned unemployment, recession, bankruptcy. At the same time he is aware that similar confusions will occur until the society stays in the iron cage of growth. In his Farewell to Growth (fr. Petit traité de la décroissance sereine) he writes: "de-growth is conceivable only in a de-growth society, or in other words within the framework of a system that is based upon a different logic" (Latouche 2009, p. 8). Jackson is of similar opinion: "(...) that challenge compels as to develop a different kind of economic structure. But it's clear that this task isn't sufficient. We also have to find a way through the institutional and social constraints that lock us into a failing system. In particular, we need to identify opportunities for change within society - change in values, change in lifestyles, change in social structure - that will free us from the damaging social logic of consumerism" (Jackson 2009, p. 102). Both of them amicably stress that nowadays we are faced with a necessity of reformulating the existing attitudes and priorities. Constraint has an essential place in that new strategy; its choice assumes the proportions of a political and economic necessity. However, it is worthwhile to clarify and distinguish what kind of constraint had in mind the above mentioned researchers. For, constraint in the qualitative aspect is not the same as constraint in the qualitative one. Equating constraint with decrease, decline, reduction, we operate in a different meaning territory, than when we talk about constraint as a situation of human choice, although in the degrowth project both those areas are interconnected. Latouche and Jackson mention 
quantitative constraint usually when talking about a new model of economic structure, and the qualitative one in the context of alteration of social logic.

"Flourishing within limits is a real possibility" argues Jackson (2009, p. 149). The first step to achieve it is accurate establishing the limits: "Establishing clear resource and environmental limits and integrating these limits into both economic functioning and social functioning is essential" (Jackson 2009, p. 173). A great deal is said about the quantitative limitation of growth, consumption greenhouse gas emissions, use of fossil fuels, and the levels the appropriate indices should reach are defined. In such a context constraint is present in many international documents and reports, i.a. the 2011 Decoupling natural resource use and environmental impacts from economic growth report issued within the frames of the United Nations Environmental Programme (UNEP), which is based on the postulate of limitation of using the natural resources to the levels allowing for their recreation (see: UNEP 2011). Referring to quantitative constrains Jackson turns the attention to the Contraction \& Convergence model developed by the Global Commons Institute. The model is used to determine the ceiling for the consumption of resources and pollution, and for defining a just limit of emissions per each citizen in relation to the emissions level in accordance with the assumed stabilization goals (see: Jackson 2009, pp. 173-174).

In order to stay in the specified ecological scale the British economist proposes a change of the economic model and signalises an urgent need to follow the path of ecological macroeconomics. He argues for a low-efficiency economy, the so-called "Cinderella economy," which is based on dematerialised services, i.e. the sector of individual and social services, and hence on an increase of investments in that industry. Jackson also turns the attention to following prudence in financial intermediation, as well as the change of economic indices, and particularly resigning from the far from perfect GDP index with the help of which one is unable to measure the quality of life and the services offered by an informal sector of economy, such as housework, social work or care (Jackson 2009, pp. 41-43, 125, 179). In turn, ecological investments leading to a long-term, effective and raw material- and energysaving consumption (energy efficiency improvement, reducing the amount of waste, recycling, prolonging the life-cycle of products, transformation of resources retardation, renewable energy sources) should become an economic priority accompanied by a taxation of environmental damages (carbon dioxide emission), as well as by engagement into repairing the losses and enhancement of the functionality of ecosystems (afforestation, restoring wetlands) (Jackson 2009, pp. 139, 211-212).

The next, probably the most important task is an attempt to change the logic of social thinking, leading attitudes and ways of behaviour. Among many possible meanings, constraint appears in this context as a situation of human choice, an intentional downgrade, or to be more precise, self-constraint. In that 
way the postulate of constraint goes beyond quantitative economic criteria and defines a particular kind of approach toward the world and a specific lifestyle related to the ideals of voluntary simplicity, simple living, minimalism, sustainable consumption. The most radical among those - voluntary simplicity - has philosophical and religious roots, which basic outline can be found, among others, in the theories of Cynics, Stoics, in Taoism, or the teaching of Mahatma Ghandi (Kronenberg \& Iida 2011, pp. 67-68). Duane Elgin argues that it also possesses a particular contemporary features. It is characterised by slowdown of life, material simplicity, bringing back the human dimension to the personal and professional life, self-control and refusal to yield to the external and social influences, ecological awareness, as well as personal development and reflectance (Elgin \& Michell 1977, pp. 4-9). The distinguished forms of consumption limitations are joined by a common idea of a better life and satisfaction from addressing non-material needs. Jackson appreciates the positive qualities of every one of them but especially privileges sustainable consumption, which in his opinion guarantees twofold benefits: improvement of life quality on account of consumption reduction and at the same time limiting out destructive impact on the environment thanks to realisation that each and every one of us is a consumer of natural resources and by our irresponsible actions we contribute to deepening of the ecological crisis (Jackson 2005, p. 25).

However, it would be naïve to think that individual endeavours to simplify life are enough: "It's clear that changing the social logic of consumption cannot simply be relegated to the realm of individual choice. In spite of a growing desire for change, it's almost impossible for people to simply choose sustainable lifestyles, however much they'd like to. (...) The chances of extending this behaviour across society are negligible without changes in the social structure" (Jackson 2009, p. 153). On the one hand conflicts arise because the individuals trying to implement the principles of limiting consumption are in opposition to the mainstream attitudes and values in the society, and on the other, such endeavours run the risk of superficial realisation of the idea of simplicity, self-constraint and sustainability, which ultimately end up as a numerous sham activities. Popkiewicz warns against that danger by showing that succumbing to masking strategies and focusing one's efforts solely on such actions as: the use of energy-efficient light bulbs, turning off the water while brushing teeth, removing the charger plug from the socket, placing a request in the E-mail footer to not to print it out due to environmental care, while driving a high-emissions car and travelling frequently by plane improves only our mood and has no real influence either on the change of the established trends, or a significant improvement of the state of the natural environment (Popkiewicz 2012, pp. 454-455). Similarly, giving in to the temptation of declined in various forms adjectives like "green" or "ecological," thoughtless following the fashion for eco-parenting, eco-products, eco-tourism, 
eco-coal does not solve the energy crisis, or the climate one. Moreover, he echoes Jackson's concerns that it is every difficult to resign from existing luxuries, what stems from the attachment to the social status confirmed by new products. The antidote for these problems, both Jackson and Latouche see in the change of social structure: "The first will be to dismantle or correct the perverse incentives for unsustainable (and unproductive) status competition. The second must be to establish new structures that provide capabilities for people to flourish, and particularly to participate fully in the life of society, in less materialistic ways" (Jackson 2009, p. 153). That list could be enlarged by the necessity of exposing and correcting the apparently sustainable actions.

The project of changing the social structure aiming at construction of a degrowth society is a challenge, which Latouche concentrates his efforts upon. The tool of change is supposed to be "the virtuous circle of quiet contraction" (fr. Le cercle vertueux de décroissance sereine), called also "the virtuous circle of degrowth" or "the virtuous circles' of eight 'R's," which particular elements create a mutually conditioned cycle of changes (see: Latouche 2004; 2003; 2005; 2009, pp. 33-43). In consists of: re-evaluate, reconceptualise, restructure, redistribute, relocalise, reduce, re-use and recycle.

Re-evaluation (fr. réévaluer) consists in rejecting a way of life characteristic for the growth society. In the opinion of the propagator of the idea of décroissance, the new axiological background should be defined by the values opposite to the middle-class ethos: altruism should take the position of egoism, collaboration - of relentless competition, the pleasure of leisure and ethos of having fun - of working obsession, the significance of social life - of unlimited consumerism, locality - of that what is global, autonomy heteronomy, the pleasure of work well done - of efficiency, rationality - of materiality, harmonious coexistence with nature - reigning over it (Latouche 2009, p. 34).

The change in the sphere of values is accompanied by reconceptualization (fr. reconceptualiser). Crucial notions and categories, like wealth and poverty, shortage and surplus require deconstruction and redefinition. Consumer culture defines shortage by artificial creation of needs and by developing in the consumer the feeling of deficit. Latouche explains that by staying within that definition sphere we are stuck in the concepts created by the growth paradigm and are unable to change. Jackson as well makes reconceptualization the central point of his considerations. He adopts a new understanding of the notion "prosperity," and defines it in a qualitative, not a quantitative variant: "Prosperity goes beyond material pleasures. It transcends material concerns. It resides in the quality of our lives and in the health and happiness if our family. It is present in the strength of our relationships and our trust in the community. It is evidenced by our satisfaction at work and our sense of shared meaning and purpose. It hangs on our potential to participate fully in the life of society" (Jackson 2009, p. 16). 
The next step in the degrowth cycle of changes is restructuring (fr. restructurer), which encompasses adjusting the production mechanisms to the described above alterations of notions and values, primarily moving towards ecological and low-emissions solutions.

Redistribution (fr. redistribuer) or restructuration in the area of social relations addresses the issue of just distribution of goods among the countries of the North and South, social classes, generations, and is supposed to serve a reduction of economic inequalities, exploitation, and poverty. Latouche strongly emphasises the need of paying back the ecological debt to the countries of the South through, among other ways, limitation of using natural resources.

Relocalising (fr. relocaliser) privileges local, collective social enterprises that limit to a necessary minimum the network of goods and capital flow (Latouche 2009, pp. 37-38). A shift towards re-establishing interpersonal relations and strengthening social and neighbourly ties should be recognised as an additional outcome of relocalisation.

The next element - reducing (fr. réduire) is closely related, according to Latouche, with reducing the impact of the mechanisms of production and consumption on the biosphere. This is why he argues for downsizing the massive tourism, which is considered as one of the main enemies of the natural environment. Also the time spent at work should be limited. Both Latouche and Jackson see a need to shorten the time of work and increasing the leisure time allowing for reflection, discussion, self-development. The policy of reducing the working time is also considered to be a tool in the fight against unemployment.

Finally, re-use (fr. réutiliser) and recycle (fr. recycler), that is all possible methods of use, processing, and re-use of waste, which should, as far as possible, be implemented already at the stage of the production of artefacts.

The group should be completed by "resist" (fr. résistance), which is a main driving force of change, an element conditioning all other parts of "the virtuous circle of quiet contraction" (Latouche 2009, p. 43). Indeed, the degrowth project stems from the need to objection the current limitations that constrict individuals; it resists the necessity to inscribe into the framework of hyper-consumerism, questions the growth paradigm, does not agree for either the manipulation of our needs and desires, or predatory exploitation of the natural development.

Justified is a question often formulated by the opponents of sustainability: Is degrowth a feasible programme? Should questioning of the need for the further economic growth be treated as a noble but abstractive model of planning future actions? Can the concept of degrowth be seen as a politico-economic project, or merely as a collocation of catchy, attentiondrawing slogans?

Latouche himself calls it utopian: "The de-growth project is therefore a utopia, or in other words a source of hope and dreams. Far from representing a flight into fantasy, it is an attempt to explore the objective possibility of its 
implementation" (Latouche 2009, p. 32). The author of Farewell to Growth treats it however as an example of "concrete utopia" understood as proposed by Ernst Bloch. In this sense Latouche perceives it as a theoretical tool that is a response to the needs and developmental trends of the current situation. He is aware that it would not be easy to implement its theses but he does not see that as a weakness. "Without the hypothesis that a different world is possible, there can be no politics, but only the administrative management of men and things" - he quotes a sociologist, Geneviéve Decrop (Latouche 2009, p. 32).

Jackson, on the other hand, is far from calling the prosperity without growth project a utopia and tellingly refuses to admit it: "For the advanced economies of the western world, prosperity without growth is no longer a utopia dream. It is a financial and ecological necessity" (Jackson 2009, p. 185). That is why he demands concrete action and engagement of the governments of the developed countries in implementing that kind of solutions and transformations.

Still, leaving behind the paradigm of economic growth is treated by many politicians and economists as unrealistic, purely theoretical postulate. The example of the undertaken actions for sustainable development shows that the process of change progresses slowly, but it does not mean that it is unfounded and unjustified. As Hull observes: "Even if the vision of sustainable development is to a large extent utopian, such a utopia - indicating the possibilities of a different way of use of nature resources, as well as social and individual life - is very needed today" (Hull 2003, p. 24).

\section{Ethical Postulate of Constraint, i.e. towards the Environmental Ethics}

The two projects, apart from strictly political and economic solutions, serve as a tool of socio-moral (Latouche 2009) or politico-ethical (Jackson 2015) change that support citizens' grass-roots endeavours to transform the lifestyle, attitudes, and behaviours. One should remember that changes of that kind cannot remain axiologically neutral even if they do not directly refer to axiology. For, a modification of attitudes is connected with the change of the evaluation approach, and thus it influences the assessment of a given situation or artefact by an individual. The quoted proponents of degrowth are aware of that and do not shy away from the language of values. They refer to axiology and ethics, and make them one of the most crucial elements of the proposed change.

The author of Farewell to Growth when elucidating the intricacies of the degrowth programme explains: "Whilst this is a political project, its implementation has more to do with an ethics of responsibility than with an ethics of conviction" (Latouche 2009, p. 66). He refers here to the introduced by Max Weber distinction between ethics focused on carrying out established moral norm (ethic of ultimate ends) and ethics that gravitates around the 
consequences of human action (ethic of responsibility) (see: Weber 1987, pp. 101-102). Ethic of responsibility aims at protection of values, and the evaluation of human choices from the point of view of the consequences for these values can be conceived as its principle. Politically engaged degrowth programme is much closer, as rightly noticed by Latouche, to an ethic of responsibility, which concentrates on moral significance of agency. It is so because the programme defines the direction of the desired social changes having regard to the economic and ecological limitations of the constant growth. It also means that the constraint postulate stemming from the objection towards a deceiving logic of consumerism, according to which 'more' always translates into 'better,' does not have the characteristic of unconditionally binding principle. Not in every situation it will be understood as an equivalent of what is good, proper, appropriate. More often it is treated as a measure and can be used for protection of the following values: life, health, justice, common good analysed in social and environmental scale. It is a collection of universal values, what speaks rather in favour of the degrowth standpoint because it increases the chance that people will be willing to act in compliance with its objectives (see: Papuziński 2013).

The postulate of constraint, which in the light if the carried out distinctions should be more precisely described as "a readiness for selfconstraint," on the one hand takes the form of a will to narrow the frames of growth, consumption, owning, exploitation of resources - in accordance with the thought behind the motto "live better by consuming less, but on the other hand, it applies to our obligations towards the natural development, other people, the contemporary and future generations, and calls for constraint for their sake. In the French thinker's opinion constraint is not about giving more but to take away less (Latouche 2009, p. 37). In contrast, Jackson, who respects the attachment of the contemporary consumers to comfort, perceives the constraint imperative not actually as a principle motivating for reducing consumption, but rather an incentive to not to consume more (Jackson 2011). It may seem that these are minimal expectations for a moral agent but this minimalism has its perks. Not being a strong opposition but merely an alternative for the established consumption patterns it does not doom the constraint postulate to immediate failure.

It is also worthy to mention that none of the researchers propagates total resignation from consuming natural and manufactured goods. They just argue that people should limit themselves to stay within the frames defined by the ecological limits of development. Therefore, a moral burden of constraint does not assume a sacrifice or absolute resignation. It is much closer to dispositions giving chance to comply various functions - social, environmental, economic - such as Aristotelian restraint, moderation or sustainability. Hence, the constraint postulate may be treated as a rule of conduct aiming for fining a proper measure for the homo sapiens - natural environment relation. So the 
readiness to limit the practices endangering the social and environmental tissue would be located between hyper-consumerism and radical resignation, extreme anthropocentrism subordinating nature to human goals and radical anti-humanism, according to which, as Latouche irreverently comments "suspected of seeing the survival of cockroaches as more important than that of human beings" (Latouche 2009, p. 97).

A degrowth developmental model proposed by Latouche, just like the one developed by Jackson with the accompanying principle of constraint, is based on two ethical pillars - the concern with the contemporary and future human well-being, and the care for the natural environment. The two thinkers see a necessary relationship between the existence of the humankind and the state of nature that conditions that existence. They are also aware that this relationship is justified and evaluated in many various ways. In the case of the extremely anthropological option the strictly service potential of the natural environment comes to the forefront, and the environment is understood exclusively as a relative value ("good for someone" or "good for something") and is entirely subjugated to human goals. In contrast, the biocentric model recognises in nature an absolute value that requires respect. Searching for an ethical justification for the importance of self-constraint, and broader, for degrowth the French researcher underlines: "Like all ecologists, advocates of de-growth are suspected of rejecting the anthropocentrism of the Enlightenment tradition in favour of an unwavering ecocentrism and, therefore, of supporting a form of deep ecology that takes an 'anti-speciesist' stance. (...) Between the extremes of the blind or dogmatic anthropocentrism of Western modernity and the animist worship of nature, there is probably room for an eco-anthropocentrism. The very survival of humanity, and therefore of humanism in what we might call the true sense of that term, means that ecological concerns must be a central part of our social, political, cultural and spiritual preoccupation with human life" (Latouche 2009, pp. 97, 103). However, Latouche would not be ready to call the degrowth programme humanism: "In my view, de-growth, in the sense that it provides the philosophical foundations for a project for an autonomous society, is probably not a humanism because it is based upon a critique of development, growth, progress, technology and, ultimately, modernity and because it implies a break with Western centralism" (Latouche 2009, p. 99).

The proposed by Latouche eco-anthropocentrism on the axiological level leans towards the signalised already moderately anthropological perspective that sees in nature both an autotelic value, as well as a service potential. Its character is impeccably recognised by Ryszard Wiśniewski. While undertaking an axiological reflection on eco-philosophy, Wiśniewski sets out a claim, which the French economist would probably agree with: "The world of values is a human world and from the perspective of this world, if one understands their own roots, they must accept nature as a bearer of absolute 
value equal the one of human life. It is one and the same axiological level that encompasses the biosphere (nature), life of individuals (personal dimension), and the existence of the species (community dimension). This axiological level is both, objective, and relative, but absolute, upon which are built values defined as spiritual, or maybe more precisely, cultural" (Wiśniewski 2015, p. 804).

The evoked remarks of axiological and ethical nature show that the degrowth programme, and in particular the supporting sustainable endeavours for the natural environment protection postulate of constraint, find their completion and justification in the environmental ethics. The luggage of protected values, preferred attitudes and desired behaviours in both cases is confluent (see: Tyburski 2011, pp. 85-157).

Piotr Krajewski, among other writers, also draws the attention to that similarity. In his article Justice and Accountability as a Basis for Sustainable Development - the Case of International Environmental Law he proposes to understand the environmental ethics as an ethics of constraint, i.e. "the choice and willingness not to abuse available resources. This ethics consists of accountability and respect for future generations which also have right to inherit the environment that fits for life and that provides opportunities for development" (Krajewski 2013, p. 15). Unfortunately, apart from that opinion, Krajewski does not develop his though any further and leaves unsatisfied yearning in regard to the supposed identity of the environmental ethics with the ethics of constraint. However, adopting even a weaker version of their mutual links, it is not difficult to see that the constraint postulate that is formulated within the socio-politico-economic degrowth project is an integral part of considerations taking place in the sphere of the environmental ethics but it does not fully cover all its problems. Within the framework of the environmental ethics the postulate of constraint mainly takes form of an efficient tool supporting eco-philosophical goals; it is treated as a means leading to make the practices affecting the natural environment more sustainable - reduction of anthropogenic pollution that is the source of the climate change, or driving down the behaviours that threaten the biosphere.

In conclusion, "a readiness to self-constraint" is a disposition at the base of which there are: firstly, the awareness of the human impact on their natural surroundings, including responsibility for the undertaken actions, or for those we restrain from; secondly, a recognition of the ethical dimension of the human being - nature relation, and hence giving the natural environment an absolute value; and finally, thirdly, the will to include nature into the scope of moral concern motivated by both, the wish to maintain the existence and secure the welfare of both, the human population, and nature as such. 


\section{Summary}

Instead of coherent conclusions closing these considerations there will be a bunch of doubts and questions we should confront against when arguing for the culture of constraint.

Firstly, we should notice that the postulate of constraint that is an alternative for unsustainable consumerism and exceeding exploitation of the natural environment is an exchange of one form of limitations for the other. The degrowth project stemming from the awareness and respect for ecological limits tries to overcome the existing institutional and social limitations; it advocates freedom from consumption, from manipulation of our needs and desires. However, it always transpires at the expense, to some extent, of the freedom of choice and individual autonomy, i.e. limiting one's own needs, the necessity of reasonable using the goods, and hence, limiting one's one comfort. These are costs that are reluctantly incurred individually and supraindividually, which have to be taken into account when considering the chances and obstacles for carrying out the degrowth project.

Secondly, it is worthy to notice that implementation of new, revolutionary ideas and projects, regardless how noble and necessary they could be, runs a risk of lack of understanding, misinterpretation, or distortion of their assumptions. Constraint requires in that matter extreme carefulness. For, there is a fine line between constrained as a free-choice situation (selfconstraint) from constraint that becomes oppression. This threat is even more justified because degrowth is not only a socio-moral strategy, but also a politico-economic one that requires support and involvement of authorities. Falling into the trap of paternalism is very plausible here (see: Szahaj 2016) and limitations incompetently imposed by the government, institutions, and the public opinion can transform sustainable, degrowth solutions into their negative opposite, and in consequence slow down or rule out the social change. Latouche is well aware of that fact. Therefore he refuses to submerge the degrowth project into the politico-electoral narration, and on that account hijacking it by political parties (Latouche 2009, pp. 95-96).

The most serious issue however is the decision to whom the constraint postulate should apply, and to what extent. The differences on the global, nation state, and local levels, such as the degree of the environment degradation, overpopulation, or problems in access to food, health care or education show that the imperative of constraint cannot be universally employed as a binding rule. In spite of the fact that it guards universal values (life, health, common good), the postulate is not a universal solution. If we deal with a lack of possibility to address the basic needs, there is nothing to limit. Therefore, it is difficult to give it a form of a goal shared on the transnational and transcultural level (although it should be noted that the problems such as climate change require a coherent, transnational low-emissions policy). This is the reason why voices present in the discussion on constraint are mainly directed towards the 
strongly economically developed countries (see: Latouche 2009, pp. 56-63; Jackson 2011). Constraint appears there in the context of ensuring equal opportunities, repayment of the ecological debt by the developed countries of the North to the countries of the South, or reducing social inequalities. Andrzej Papuziński referring to the opinion of Edith Brown-Weiss stresses that intraand inter-generational justice imposes on affluent societies the obligation to support poor societies and social groups in the access to the global wealth, to the common civilization and natural heritage. Moreover, these countries should also pay the costs of implementation of pro-ecological policy in the world (Papuziński 2014, pp. 24-25). According to Papuziński, it does not mean however that "the developing countries should be provided with the same chances for economic growth as the contemporary prosperous North had in the past when it accumulated its wealth without caring for the environmental outcomes of its economic activities" (Papuziński 2014, p. 15). In a similar manner, both Latouche and Jackson amicably emphasise that the countries of the South need an economic growth, but such that will allow them to avoid the traps the highly developed countries have fallen into. If developing countries are not to become slaves of material comfort, it is necessary for them to affirm their autonomy and moving towards self-sufficiency. Therefore, the degrowth project should be tailored to their needs. Limitation of the consumption, growth, exploitation of resources is not, in their case, essential path, although its implementation in the developed countries provides a chance for carrying out an alternative model in the countries of the South. Latouche characterises this model in the following way: "If we dare to implement de-growth in the South, we can attempt to trigger a spiral moment that will bring us into the orbit of the virtuous circles of the three 'R's, such as Rompre [break], Renew, Rediscover, Reintroduce Recuperate, and so on. Break away from economic and cultural dependency on the North. Renew contact with the thread of a history that was interrupted by colonization, development and globalization. Rediscover and reappropriate the cultural identity of the South. Reintroduce specific products that have been forgotten or abandoned, and 'anti-economic' values that are bund up with the past of these countries. Recuperate traditional technologies and skills" (Latouche 2009, p. 58).

Considering the choice of constraint as a contemporary moral postulate, and at the same time a socio-cultural, political and economic necessity, it is worthwhile to take into account the signalised traps. The sketched doubts should not scare off but rather encourage more careful and critical observation of the postulate of constraint that occupies increasingly significant place in sociology, economy, political science, and ethics, particularly environmental ethics. 


\section{References}

Ariés, P. 2005. Décroissance ou barbarie. Villeurbanne: éditions Golias.

Bauman, Z. 2015. "O przemijaniu trwania”. In K. Kuligowska \& C. ObrachtProndzyński (eds.) Śmieć w kulturze. Gdańsk: Wydawnictwo Naukowe Katedra.

Ciążela, H. 2015. "Wokół biologii, ekonomii, moralności. Miejsce Thomasa Roberta Malthusa w historii etyki". In P. Domeracki, A. Grzeliński, \& R. Wiśniewski (eds.) Filozofia-Etyka-Ekologia. Profesorowi Włodzimierzowi Tyburskiemu $w$ darze (pp. 491-499). Toruń: Wydawnictwo Naukowe Uniwersytetu Mikołaja Kopernika.

EEA Signals. 2009. "Key environmental issues facing Europe". URL: http://www.eea.europa.eu/publications/signals-2009 (retrieved on 22.12.2015)

Elgin, D. \& A. Michell. 1977. "Voluntary Simplicity." The Co-Evolution Quarterly, Vol. Summer: 1-40.

Gorz, A. 1994. Capitalism, Socialism, Ecology. London: Verso.

Hall, C. A. S. \& J. W. Day. 2009. "Revisiting the Limits to Growth After Peak Oil." American Scientist, Vol. 97: 230-237.

Harrdin, G. 1968. "The Tragedy of Commons." Science, Vol. 162: 1243-1248.

Helm, D. 2009. Environmental Challenges in a Warming World: Consumption, Costs and Responsibilites. Oxford: New College.

Hull, Z. 2003. "Wartości ekologiczne dla zrównoważonego rozwoju". In A Pawłowski (ed) Filozoficzne $i$ społeczne uwarunkowania zrównoważonego rozwoju. Warszawa: Monografie Komitetu Inżynierii Środowiska.

Hull, Z. 2008. "The Philosophical and Social Conditioning of Sustainable Development." Problemy Ekorozwoju Vol. 3: 27-31.

Jackson, T. 2005. "Live Better by Consuming Less? Is There a «Double Dividend» in Sustainable Consumption?" Journal of Industrial Ecology, Vol. 9: 1936.

Jackson, T. 2009. Prosperity Without Growth: Economics for a Finite Planet. London: Earthscan Press.

Jackson, T. 2011. "Żelazna klatka konsumpcjonizmu”. Instytut Obywatelski 30.09.2011. URL: http://www.instytutobywatelski.pl/2687/lupainstytutu/zelazna-klatka-konsumpcjonizmu (retrieved on 22.01.2016)

Krajewski, P. 2013. "Justice and Accountability as a Basis for Sustainable Development - the Case of International Environmental Law." Problemy Ekorozwoju, Vol. 7: 15-31.

Krall, H. 2015. "Było dużo niepokoju." In M. Nogaś (ed) Z najwyższej półki. URL: http://www.polskieradio.pl/9/874/Artykul/1489430,Hanna-Krallbylo-duzo-niepokoju (retrieved on 22.12.2105).

Kronenberg, J. \& N. Iida. 2011. "Simple Living and Sustainable Consumption." Problems of Sustainable Development, Vol. 2: 67-74. 
Latouche, S. 2003. "Absurdité du productivisme et des gaspillages. Pour une société de décroissance". Le Monde Diplomatique, Vol. Novembre.

Latouche, S. 2004. "Contre l'ethnocentrisme du développement. Et la décroissance sauvera le Sud..." Le Monde Diplomatique, Vol. Novembre.

Latouche, S. 2005. "Vers la décroissance. Écofascisme ou écodémocratie". Le Monde Diplomatique, Vol. Novembre.

Latouche, S. 2007. "Petit traité de la décroissance sereine". Paris: Mille et Une Nuits.

Latouche, S. 2009. Farewell to Growth. Cambridge: Polity Press.

Malthus, T.R. 2003. Prawo ludności. Warszawa: Wydawnictwo De Agostini.

Meadows, D., J. Rander, \& W. W. Behrens III. 1972. The Limits to Growth. A report to the Clube of Rome. New York: Univers Books.

Meadows, D., J. Randers, \& D. Meadows. 2004. Limits to Growth: the 30-Year Update. London: Earthscan.

Norton, B. G. 2005. Sustainability. A Philosophy of Adaptive Ecosystem Managment. Chicago: Chicago University Press.

Olson, M. \& H. H. Landsberg. 1973. The No-Growth Society. New York: Norton \& Company.

Papuziński, A. 2013. "The Axiology of Sustainable Development: An Attempt at Typologization." Problems of Sustainable Development, Vol. 8: 5-25.

Papuziński, A. 2014. "Sustainable Development in the Context of the Theory of Intergenerational Justice. An Attempt to Specify a Problem." Studies in Global Ethics and Global Education, Vol. 2: 12-27.

Popkiewicz, M. 2012. Świat na rozdrożu. Katowice: Wydawnictwo Sonia Draga.

SDC. 2003. Redefining Prosperity. London: Sustainable Development Commision.

URL:

http://www.sdcommission.org.uk/data/files/publications/030627\%20Redefining\%2 0prosperity,\%20resource\%20productivity.pdf (retrieved on 22.12.2015).

SDC. 2011. Know your environmental limits. A local leaders' guide. London: Sustainable Development Commision. URL: http://www.sdcommission.org.uk/data/files/publications/know_your_env_limits1.pdf (retrieved on 22.12.2015).

Stern, N. 2007. The Economics of Climate Change: The Stern Review. Cambridge: Cambridge University Press.

Stern, N. 2010. Globalny ład. Warszawa: Wydawnictwo Krytyki Politycznej.

Szahaj, A. 2016. "Napędzanie konsumpcji, czyli jak wielki biznes ogranicza naszą wolność". Dziennik Gazeta Prawna z dn. 16.01.2016. URL: http://forsal.pl/artykuly/916688,napedzanie-konsumpcji-czyli-jakwielki-biznes-ogranicza-nasza-wolnosc.html (retrieved on 22.01. 2016).

Turner, G. 2008. A Comparison of the Limits to Growth with Thirty Years of Reality. CSIRO. Vol. June. URL: 
hhht:/ecsim.org/Vista/archivos/TURNER\%20G\%20-

\%20TLG\%2030\%20years\%20comparison\%20to\%20reality.pdf

(retrieved on 22.12.2015).

Tyburski, W. 2011. Etyka środowiskowa i jej wkład w budowanie świadomości sprzyjającej wdrażaniu idei zrównoważonego rozwoju In Tyburski, W. (ed) Zasady kształtowania postaw sprzyjajacych wdrażaniu zrównoważonego rozwoju (pp. 85-157). Toruń: Wydawnictwo Naukowe Uniwersytetu Mikołaja Kopernika.

UNEP. 2011. "Decoupling Natural Resource Use and Environmental Impacts from Economic Growth." United Nations Environment Programme. URL: http://www.unep.org/resourcepanel/decoupling/files/pdf/ Decoupling_Report_English.pdf (retrieved on 22.15.2015).

Weber, M. 1987. Polityka jako zawód i powołanie. Warszawa: Niezależna Oficyna Wydawnicza.

Weitzman, M. L. 2007. A Review of "The Stern Review of the Economics of Climate Change." Journal of Economic Literature, Vol. XLV: 703-724.

Wiśniewski, R. 2015. "Aksjologia ekologii”. In P. Domeracki, A. Grzeliński, \& R. Wiśniewski (eds.) Filozofia-Etyka-Ekologia. Profesorowi Włodzimierzowi Tyburskiemu $w$ darze (pp. 793-806). Toruń: Wydawnictwo Naukowe Uniwersytetu Mikołaja Kopernika.

WWF. 2006. Living Planet Report 2006. URL: http://d2ouvy59p0dg6k.cloudfront.net/downloads/living_planet_report .pdf (retrieved on: 22.12.2015) 
Iwona Stachowska

(The Maria Grzegorzewska University in Warsaw, ivsta@wp.pl)

\title{
Constraint As an Ethical Postulate in the Context of Ecological Limits
}

\begin{abstract}
The problem of natural resources being finite as well as the capability of ecosystems and the biosphere to assimilate the effects of economic activity on the one hand, and growing economic discrepancies on the other raise a question mark over the chase after the unrestrained economic growth. In the search for alternative models of thinking and development a significant role of constraint is being more and more emphasized. In the case of ecological barriers limitation of using nonrenewable resources, greenhouse gases emissions, excessive consumption and production seems to be a reasonable strategy that manifests our care for the natural environment.

The aim of the paper is to demonstrate that the postulate of constraint present in the de-growth model in the form proposed by Tim Jackson and Serge Latouche apart from a quantitative dimension has, above all, a qualitative and ethically orientated dimension. Constraint conceived in the above way stays close to terms like moderation, restraint, sustainability, i.e. such terms that possess solid ethical foundations and constitute an important base for environmental ethics.
\end{abstract}

Keywords: limitation, ecological constraint, degrowth, environmental ethics Ethics in Progress (ISSN 2084-9257). Vol. 7 (2016). No. 1, Art. \#2, pp. 01-20. doi: 10.14746/eip.2016.1.1 